\title{
Size-fractionated chitin contribution to seston, with linkages to the copepod Acartia
}

\author{
Florencia Biancalana ${ }^{1 * \bullet}$, Anabela Anahí Berasategui ${ }^{1 \oplus}$ \\ ${ }^{1}$ Instituto Argentino de Oceanografía (IADO), Universidad Nacional del Sur (UNS)-CONICET, La Carrindanga Km 7.5, B8000FWB Bahía \\ Blanca, Argentina \\ *Corresponding author: biancaf@criba.edu.ar
}

\section{Abstract}

The main purpose of the present work was to determine chitin from experimental size-fractioned incubations of the copepod Acartia tonsa, considered one of the primary sources of chitin in the Bahía Blanca Estuary. Sampling was performed during the austral warm season at one station in 2014 and 2015. Field-collected females (200 individuals) and males (100 individuals) were incubated in $8 \mathrm{~L}$ containers in the laboratory simulating in situ environmental conditions of temperature and salinity for 72 hours. Chitin content was measured in different size fractions (20-60, 60-135 and $\geq 135 \mu \mathrm{m}$ ). Particulate organic matter and dry weight were also determined in the different size fractions. Highly agglutinated debris, pellets, and natural food (diatoms and tintinnids) were observed in the $20-60 \mu \mathrm{m}$ size fraction, with a maximum of $0.68 \pm 0.21 \mathrm{mg} \mathrm{L}^{-1}$ chitin, and the highest contribution of chitin to POC ( $34.62 \pm 18.50 \%)$. Eggs, nauplii and natural food (diatoms and tintinnids) were observed in the 60-135 $\mu \mathrm{m}$ size fraction, with a maximum of $0.20 \pm 0.12 \mathrm{mg} \mathrm{L}^{-1}$ chitin and a contribution to POC of $9.80 \pm 5.00 \%$. Acartia adults and their exuviae were observed in the $\geq 135 \mu \mathrm{m}$ size fraction, with a maximum concentration of chitin of $0.67 \pm 0.40$, and a maximum contribution of chitin to POC TS of $30.47 \pm 27.23 \%$. Differences were detected between the different fractions in chitin, POC and DW, indicating that the $20-60$ and $\geq 135 \mu \mathrm{m}$ size fractions were both an important contribution of chitin in the experiment. Our results suggest that pellets, carcasses and exuviae along with natural food and organic aggregates were the main source of chitin in this system.

Descriptors: Chitin, Acartia tonsa, Organic matter, Estuary.

\section{INTRODUCTION}

Chitin is composed by a poly- $\beta-1,4-\mathrm{N}$-acetyl-Dglucosamine, is one of the most abundant biopolymer in the ocean with a global production rates estimated at approximately $10^{10}-10^{11}$ tons year ${ }^{-1}$ (Gooday, 1990). It is found in numerous marine organisms, including cell walls of fungi, yeast, cyst walls of some ciliates and amoebae, lorica walls of some ciliates, and diatoms (e.g., genera Thalassiosira and Skeletonema);

Submitted on: 7/ November/2019

Approved on: 7/May/2020

Associate Editor: Hans G. Dam

Editor: Rubens M. Lopes

(i) 02020 The authors. This is an open access article distributed under the terms of the Creative Commons license. it is also the main component of the exoskeleton of crustaceans (Gooday, 1990; Smucker, 1991). Studies on zooplankton and benthic communities of the Mediterranean Sea have shown that the total chitin quantification in the whole marine biocycle would be at least 2.3 million metric tons per year (Jeuniaux and Voss-Foucart, 1991). Among crustaceans, Copepods are a main source of chitin in temperate and tropical latitudes (Jeuniaux and Voss-Foucart, 1991). The copepod chitin stock based on the chitin product of individual chitin content and abundance exceeds billions of tons in the marine environment (Johnstone, 1908; Jeuniaux and Voss-Foucart, 1991).

Processes such as molting, pellet and egg production, and carcass production contribute 
copepod chitin, which is incorporated into "marine snow" (organic matter aggregates $\geq 0.5 \mathrm{~mm}$ in diameter) (Alldredge and Gostschalk, 1990; Simon et al., 2002; Turner, 2002). Degradation processes by chitinolytic organisms, particularly bacteria, take place in these aggregates, constituting the key step in degrading chitin to carbon and nitrogen in marine systems (Beier and Bertilsson, 2013). Living copepods and their exuviae contribute hot spots in which bacterial degradation processes transform chitin into biologically useful material that can be used by the entire marine food web in the marine environment (Souza et al., 2011; Tang et al., 2010).

The cosmopolitan copepod Acartia tonsa is the dominant species in many subtropical-temperate estuaries and marine coasts (Mauchline, 1998). It has been intensively studied, since it is easily kept in culture (Kiørboe et al., 1985; Stottrup, 2000; Broglio et al., 2003; Calliari et al., 2006; Peck and Holte, 2006; Calliari et al., 2008). Wild populations have been studied in several estuaries, given their central role as secondary producers in their trophic chain (Heinle, 1966; Durbin and Durbin, 1981; Escaravage and Soetaert, 1995; Muxagata et al., 2012; Leandro et al., 2014). Acartia tonsa is considered one of the key species in the Bahía Blanca Estuary (BBE), Argentina, and shows the highest abundance values (120010869 ind. $\mathrm{m}^{-3}$ ) during the warm season (Sabatini, 1989; Hoffmeyer, 2004; Dutto et al., 2012; Berasategui et al., 2016). Previous studies on chitin quantification on seston samples from the BBE suggested that most the chitin was micro-detritus from exuviae and pellets of $A$. tonsa during the warm season (Biancalana et al., 2017a; Biancalana et al., 2019). However, little is known about the production and stock of chitin by this copepod and its contribution to the seston in this ecosystem. It can be inferred that $A$. tonsa could be the primary source of this biopolymer in this system, as it occurs in other estuaries in the warm season.

In this study, we measured chitin concentrations in incubations of different size fractions of seston in the presence of the copepod Acartia tonsa. Laboratory incubations of adult of $A$. tonsa were performed during its peak production season in the BBE. In addition, the particulate organic carbon (POC) and the dry weight (DW) in each fraction were measured to determine their relationship with chitin supply. This work provides information about which chitinous material from $A$. tonsa, particularly the one formed by chitin, was part of the organic matter aggregates in this estuarine system.

\section{MATERIAL AND METHODS}

\section{STUDY AREA}

The BBE $\left(38^{\circ} 44^{\prime}-39^{\circ} 27^{\prime} S\right.$ and $\left.61^{\circ} 45^{\prime}-62^{\circ} 30^{\prime} \mathrm{W}\right)$ is a mesotidal, temperate and turbid estuary, located in the southwestern Atlantic Ocean (Figure 1). Sampling and in situ measurements were performed at Cuatreros Port $(C P)$, which is located in the innermost area of the BBE. This zone shows a marked seasonal variation in water temperature $\left(5-27^{\circ} \mathrm{C}\right)$ and salinity (17.3-41.9), being hypersaline during warm seasons (Freije et al., 2008). The annual mean concentration of dissolved oxygen is close to $\sim 7 \mathrm{mg} \mathrm{L}^{-1}$, reaching greater values during phytoplankton blooms in winter and late summer (Freije et al., 2008; Popovich and Marcovecchio, 2008). Suspended sediment concentrations vary between 30 and $400 \mathrm{mg} \mathrm{L}^{-1}$ (Perillo et al., 2001). The system is characterized by high concentrations of planktonic and detrital biomass of native and autochthonous origin that is part of the natural diet of zooplankton, which in turn is a food staple for several species of fish commercial interest (Diodato and Hoffmeyer, 2008; Guinder et al., 2010).

The phytoplankton dynamics in the BBE have been studied over the past three decades; the annual cycle has been characterized by a diatom bloom belonging to the genera Thalassiosira and Chaetoceros (Guinder et al., 2010). Phytoplankton follows a bimodal pattern, with an important winter bloom of $8000-9000 \times 10^{3}$ cells. $\mathrm{L}^{-1}$ and a summer bloom of smaller magnitude (1500-2000 $\times 10^{3}$ cells. $\left.\mathrm{L}^{-1}\right)$, with predominance of the diatom Thalassiosira minima (Guinder et al., 2010; Guinder et al., 2012). Among the microzooplankton, loricated ciliates (tintinnids), mainly the small species belonging to the genera Tintinnidium, Leprotintinnus, Tintinnopsis, and Codonellopsis, have higher abundances in summer and autumn $\left(10 \times 10^{3}\right.$ ind. $\mathrm{L}^{-1}$ and $5 \times 10^{3}$ ind. $\mathrm{L}^{-1}$ ) (Pettigrosso and Barría de Cao, 2007). Within mesozooplankton, copepod species are mainly represented by Acartia tonsa, which has an annual mean abundance of 695.48 ind. $\mathrm{m}^{-3}$, being this copepod the predominant holoplanktonic species of BBE (Berasategui et al., 2018). This species is found in the water column 


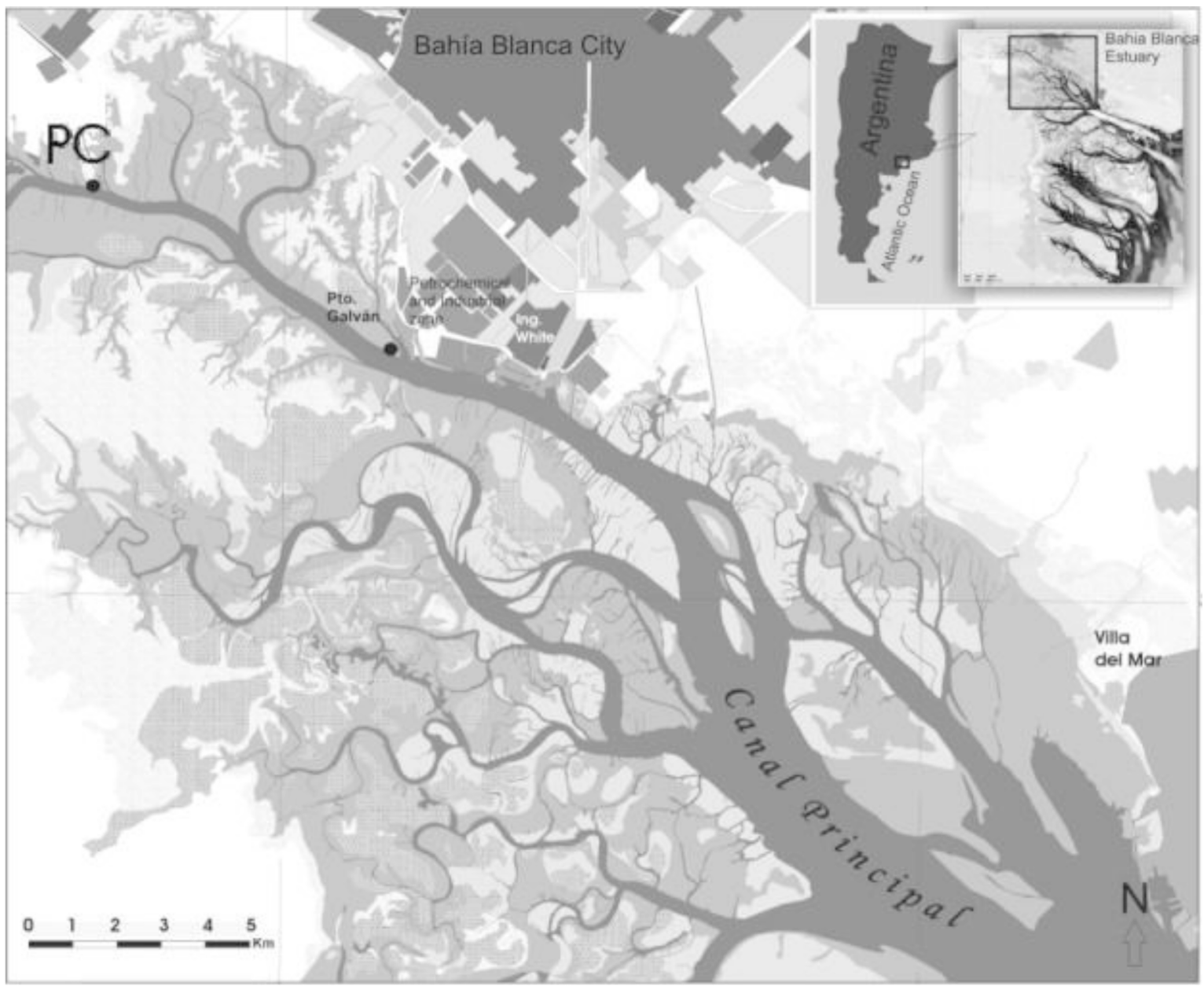

Figure 1. Map of the Bahia Blanca Estuary, showing Cuatreros Port ( $C P$, upper left side).

throughout the year, with a maximal abundance during the warm season (austral summer: December to March,) and minimal abundance during the cold season (austral winter: June to August) (Berasategui et al., 2018). In particularly, A. tonsa was the most abundant (4342 \pm 3197 ind. $\mathrm{m}^{-3}$ ) component of the mesozooplankton (5593.39 ind. $\mathrm{m}^{-3}$ ), in the Cuatreros Port during this study period (data unpublished).

\section{SAMPLING PROCEDURES AND METHODS}

Sampling was performed during times of greatest Acartia tonsa production (Sabatini, 1989; Hoffmeyer, 2004; Dutto et al., 2012; Berasategui et al., 2016) in the BBE, in two consecutive years (18 February 2014, 18 March 2014 and 21 April 2014; 09 December 2014, 12 January 2015 and 23 February 2015). On each sampling date, females and males of $A$. tonsa were obtained through four oblique hauls of 10 minutes each one, working in the opposite direction of the ebb tide. The hauls were done using a plankton net of $200 \mu \mathrm{m}$ - mesh and $0.30 \mathrm{~m}$ diameter with a solid cod end to avoid damage to the specimens. Subsequently, each haul was filtered through a $1.5 \mathrm{~mm}$ sieve to remove the predominant mesozooplanktonic predators, such as Parasagitta sp., ichtyoplankton, small jellyfish and ctenophores (Hoffmeyer, 2007; Dutto et al., 2017). Then, the sample was placed in $10 \mathrm{~L}$ bottles and transported in a thermal container to maintain the environmental temperature ( one hour) until arrival at the laboratory.

On each sampling date, surface water (0.5 $\mathrm{m}$ depth) samples were also collected using 10-20 L PET bottles for the incubation medium. Surface temperature and salinity were recorded using a PCE-PHD1 at the same time of the sample collection. 


\section{LABORATORY PROCEDURES}

The seawater extracted to be used as incubation medium was previously filtered to a $60 \mu \mathrm{m}$ sieve. This pore size was chosen considering the optimum size range $(15-70 \mu \mathrm{m})$ of Acatia tonsa adult prey (Berggreen et al., 1988) and to avoid the introduction of other copepod nauplii and Grapsidae zoea present in the BBE during the warm season (Hoffmeyer, 2007).

Live mesozooplankton samples ( $10 \mathrm{~L}$ bottles) were diluted using in situ filtered seawater $(\leq 60 \mu \mathrm{m})$ and transferred into plastic $20 \mathrm{~L}$ containers for acclimation ( 24 hours). Adult specimens were subsequently selected under stereomicroscope for experimental incubation. A total of 200 females and 100 males were placed in an incubation bottle filled with $8 \mathrm{~L}$ of in situ filtered seawater (37 individuals $\mathrm{L}^{-1}$ ). Three incubations bottles $(n=3)$ were simultaneously performed (Figure 2). The first incubation bottle was used to determine chitin in different fractions (Figure 2A); the second bottle was used to determine POC per fractions (Figure $2 \mathrm{~B}$ ); the third bottle was used to analyze the composition (nauplii, eggs, pellets, exuviae) in each studied fraction (Figure 2C). These incubation sets were performed in turn on each sampling date.

The incubations were carried out in a culture chamber for 72 hours at $18 \pm 1{ }^{\circ} \mathrm{C}$, salinity of $32 \pm 2$, and $\sim 16$ hours light (Berasategui et al., 2018). Aeration with bubble air was provided into the culture medium to avoid the decrease of oxygen. At the end of the incubation time, each experimental incubation was filtered through a set of sieves of 135-60-20 $\mu \mathrm{m}$ to determine the contributions of chitin and carbon by Acartia tonsa (Figure 2). These fractions were chosen considering the size and development of adults, eggs and nauplii (Sabatini, 1989; Leandro et al., 2006; Berasategui et al., 2016): Fraction I, between 20-60 $\mu \mathrm{m}$ and composed of fecal pellets, remains of nauplii, and chorion of hatched eggs $(88 \pm 37-168 \pm 35$ fecal pellet length, $40 \pm 6-37 \pm 8$ fecal pellets width; Hansen et al., 1996); Fraction II, between 60-135 $\mu \mathrm{m}$ and composed of eggs (85-100 $\mu \mathrm{m}$; Berasategui et al., 2016), nauplii (Leandro et al., 2006), and disintegrated remains of adult and nauplii exuviae; and Fraction III, $\geq 135 \mu \mathrm{m}$ and composed by live and dead adults (size 1-1.3 mm, Sabatini, 1989). Samples were fixed in buffered formalin ( $4 \%$ formaldehyde diluted in filtered seawater), and the fixed samples examined under a Nikon SMZ 1500 stereoscopic microscope. The number of eggs as unhatched eggs (UE), chorion of hatched eggs $(\mathrm{HE})$, death ratio (DR\%; total death individuals in the experimental bottle/initial total individuals in the experimental bottles), number of pellets, carcasses, exuviae and nauplii were determined from these samples. Before filtering all the content of incubation bottle through the different size sieves (see Figure 2C),

A) Experimental set for chitin determination B) Experimental set for POC determination C) Experimental set for quali-quantitative analysis

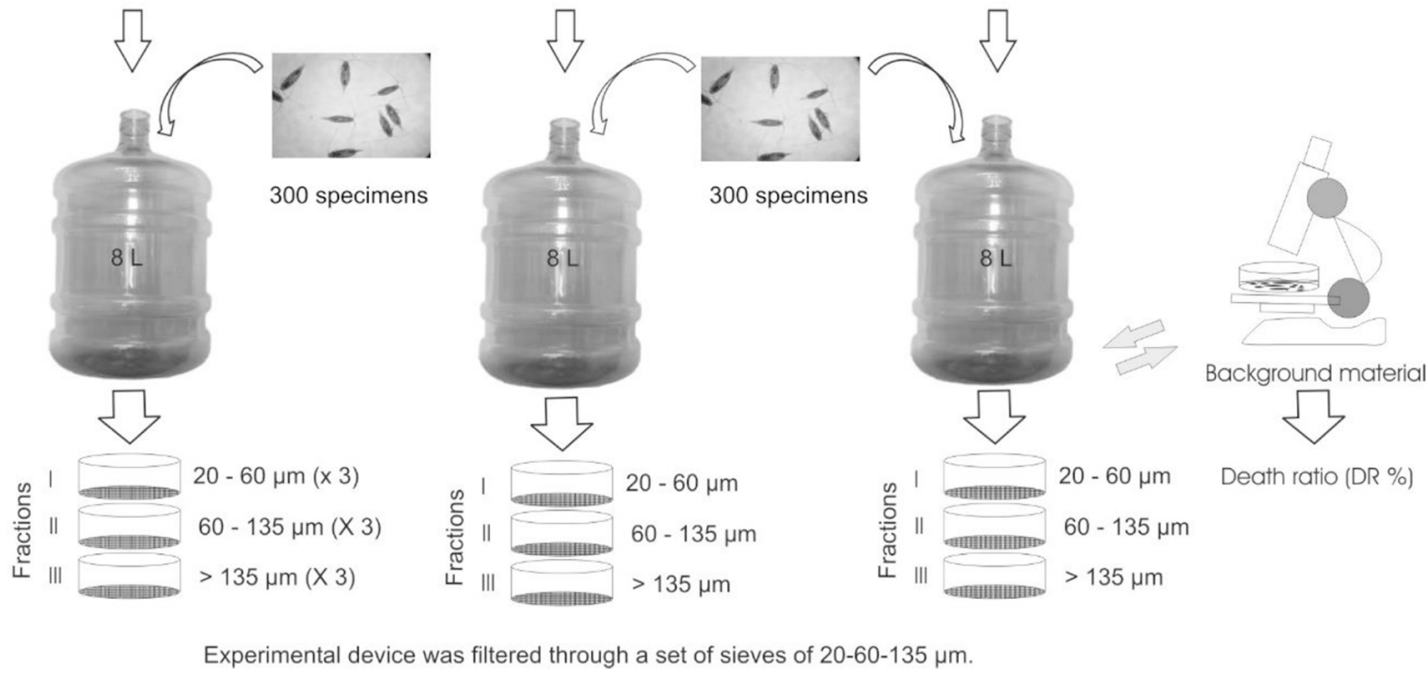

Figure 2. Methodological diagram showing the procedure for incubation and determinations in seston size fractions. ${ }^{*} \mathrm{DR} \%$; total death individuals in the experimental bottle/initial total individuals in the experimental bottles. 
the settled portion was used to observe the number dead organisms under a stereoscopic microscope in order to calculate DR\%.

For all the determinations, the material filtrated through the different sieves mentioned before was taken to $\sim 500 \mathrm{~mL}$ with filtered seawater (aged, filtered by 1 and $0.7 \mu \mathrm{m}$, filter pore, and autoclaved). For chitin determination, the samples were vacuumfiltered using glass fiber filters (GF/F - $0.7 \mu \mathrm{m}$ pore) that were previously burned at $450{ }^{\circ} \mathrm{C}$ for $4 \mathrm{~h}$. Then, the filters were dried at $50^{\circ} \mathrm{C}$ for $12 \mathrm{~h}$. Chitin content was measured by the FITC-WGA-method following Montgomery et al. (1990). The method was calibrated with purified crab chitin (Sigma-Aldrich, St. Louis, MO, USA) as standard and quantified by fluorometric measurement of excess wheat germ agglutinin (WGA) after its reaction with fluorescein isocyanate (FITC). The chitin quantification ( $\left.\mathrm{mg} \mathrm{L}^{-1}\right)$ in each fraction was made it by triplicate. Material samples for particulate organic carbon (POC, $\mathrm{mg} \mathrm{L}^{-1}$ ) determination were filtered through muffled (450 ${ }^{\circ} \mathrm{C}, 1 \mathrm{~h}$ ) glass fiber filters (GAMAFIL-GF/F - $0.7 \mu \mathrm{m}$ pore). The POC concentration $(\mu \mathrm{M})$ was measured following the Strickland and Parsons (1968), using a UV-Vis Jenway 6715 spectrophotometer. Only one determination was made in each fraction. The dry weight of seston (DW, $\mathrm{mg} \mathrm{L}^{-1}$ ) for each fraction and each month was determined gravimetrically after drying at $50^{\circ} \mathrm{C}$ to a constant weight.

\section{STATISTICAL ANALYSES}

Two-way analysis of variance (ANOVA) was used to detect differences on the concentration of chitin ( $\left.\mathrm{mg} \mathrm{L}^{-1}\right), \mathrm{POC}\left(\mathrm{mg} \mathrm{L}^{-1}\right)$ and DW (mg L-1) monthly and by fraction. The chitin concentration and POC were square root transformed to meet the assumptions or normality and homoscedasticity for the ANOVA. When statistical differences were detected in the two-way ANOVA analysis, a post-hoc Tukey's test was applied to detect in which seston fraction and months there were significant effects on the concentration chitin, POC and DW. This analysis was conducted at a significant level of 0.05 , by SPSS 15.0 software. Permutational Multivariate Analysis of Variance (PERMANOVA) was applied to detect the differences in the patterns of variables regarding fractions and months, also using square root transformations. The Bray-Curtis similarities matrix was used in the analyses above. These analyses were done using the PRIMER 6 software. Undetectable POC values for January 2015 were assumed to be zero for, the Twoway ANOVA and PERMANOVA analyses. Thus, the differences found in this variable could have been overestimated.

\section{RESULTS}

The maximum concentration of chitin was $0.68 \pm 0.21 \mathrm{mg} \mathrm{L}^{-1}$ in the fractions $20-60 \mu \mathrm{m}$ in January 2015 (Figure 3). The highest contribution of chitin to POC $(34.62 \pm 18.50 \%)$ was observed in this fraction in December 2014, and the highest contribution of this polymer to DW (12.58 $\pm 3.97 \%)$ was observed in January 2015 (Figure 3). Highly agglutinated debris, copepod pellets, and natural food (diatoms and tintinnids) were observed in this fraction (Figures 4A and 4D).

The concentration of chitin in the 60-135 $\mu \mathrm{m}$ size fraction was lower than in the 20-60 $\mu \mathrm{m}$ size fraction during the whole study (Figure 3 ), with a maximum chitin concentration of $0.20 \pm 0.12 \mathrm{mg} \mathrm{L}^{-1}$, contributing $25.41 \pm 14.97 \%$ to DW in April (Figure 3). The highest contribution of chitin to POC $(9.80 \pm 5.00 \%)$ was observed in this fraction in December 2014. In this fraction, UE and HE and nauplii were mostly observed. In addition, agglutinated debris, carcass remains and natural food (diatoms and tintinnids) were also observed (Figures 4B and 4D).

In the $\geq 135 \mu \mathrm{m}$ size fraction, the highest values of $0.67 \pm 0.40 \mathrm{mg} \mathrm{L}^{-1}$ was observed in January 2015 (Figure 3). The maximum contribution of chitin to POC was $30.47 \pm 27.23 \%$ in February 2014 and its contribution to DW was $35.08 \pm 20.63 \%$ in February 2014. Acartia tonsa adults (carcasses) and exuviae dominated this fraction (Figures 4C and 4D).

Significant differences were detected in chitin concentration and DW between seston fractions (Twoway ANOVA, $p \leq 0.05$ ) (Table 1, Figure 5 ). There were no differences in POC (Two-way ANOVA, $p=0.05$ ) between seston fractions (Table 1, Figure 5). Differences in the POC and DW (Two-way ANOVA, $p \leq 0.05$ ) were found between months, but not in the chitin concentration (Two-way ANOVA, $p=0.05$ ) (Table 1, Figure 5). Significant differences in DW were detected between the 20-60 $\mu \mathrm{m}$ size fraction and the remaining fractions (20-60 and $\leq 135 \mu \mathrm{m}$ ) (Tukey's test, $p \leq 0.05$ ). Also, significant monthly differences were found in the concentration of DW between March and April 2014, 


\section{Experimental period}

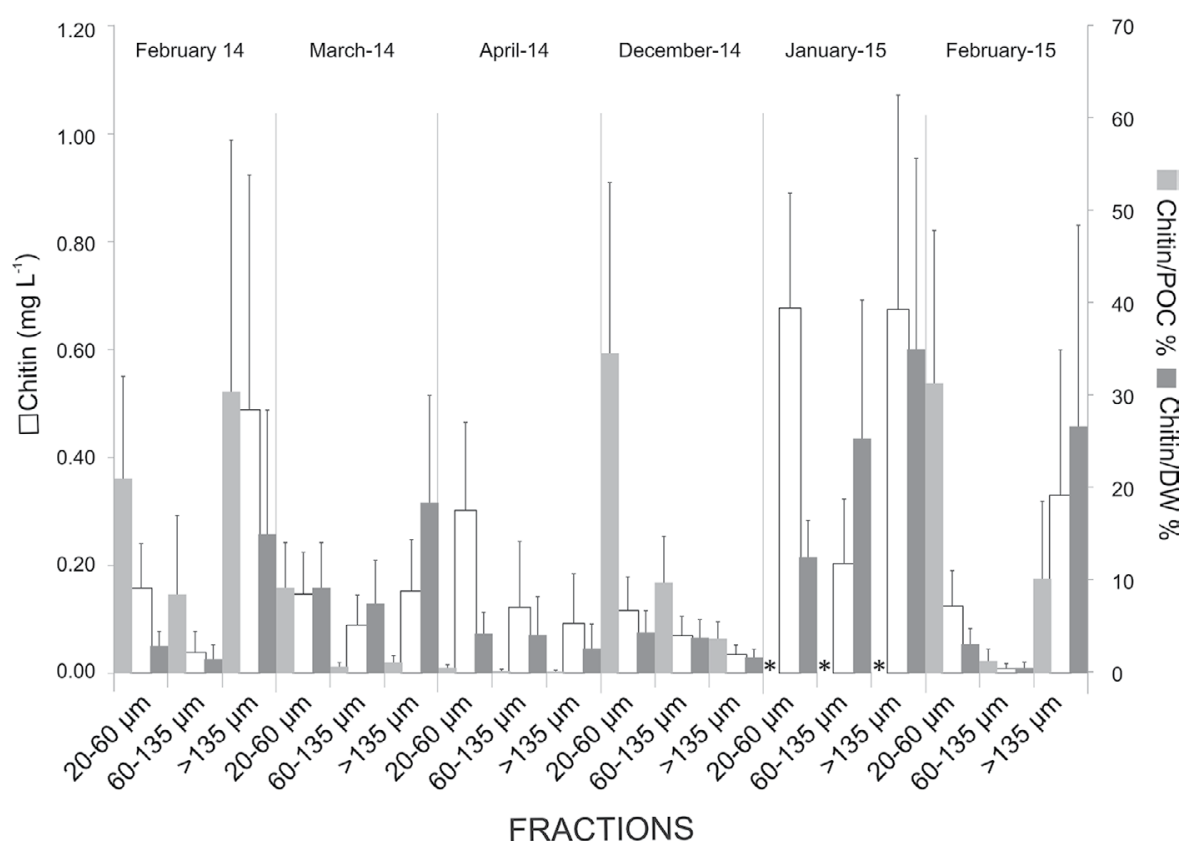

Figure 3. The concentration of chitin $\left(\mathrm{mg} \mathrm{L}^{-1}\right)$, the proportion of chitin in DW, and POC (chitin/DW\% and chitin/POC\%, respectively) (mean \pm $\mathrm{SE})$ in seston size fractions during the experimental period. SE: Standard Error; * no detected.
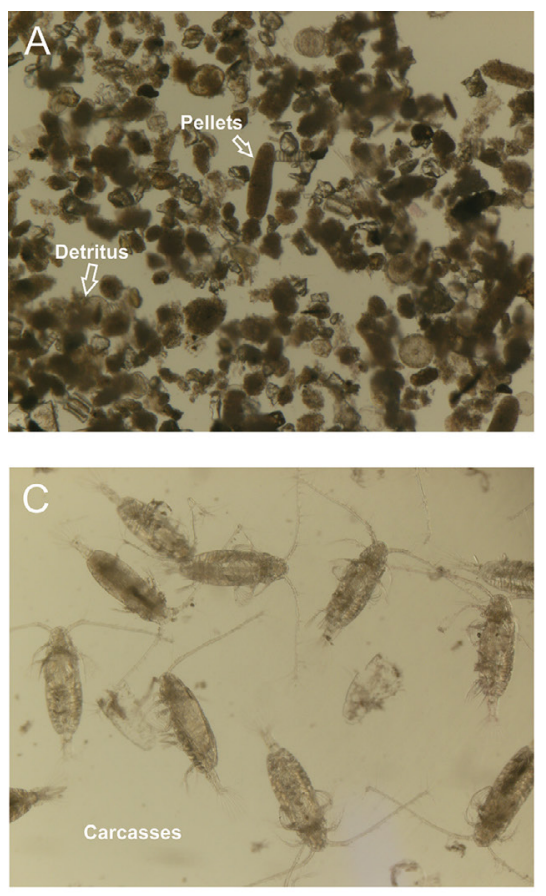

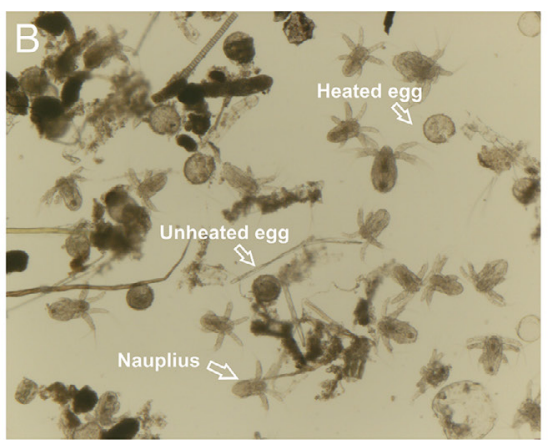

D
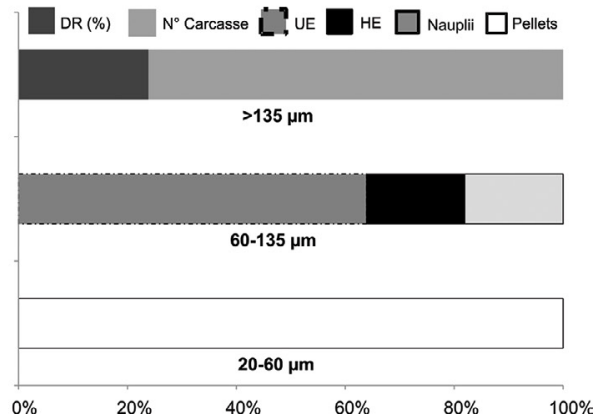

Figure 4. A-D. Images captured by a Nikon SMZ 1500 stereomicroscope: A. Sestonic aggregates composed of pellets, detritus, phytoplankton, and ciliates in fraction 20-60 $\mu \mathrm{m}$ (6X); B. Unhatched and hatched eggs (UE and HE, respectively), and nauplii together with detritus and natural food (diatoms and tintinnids) in fraction 60-135 $\mu \mathrm{m}$ (6X); C. Adults of A. tonsa and molts in fraction $\geq 135 \mu \mathrm{m}$ (11.25X); $\mathbf{D}$. Percentage of death ratio $-\mathrm{DR}(\%)$, number of carcasses, $\mathrm{UE}, \mathrm{HE}$, nauplii and pellets in each fractions size. 
Table 1. The results of the two-way ANOVA applied in the chitin concentration, $P O C$ and DW by months and size fractions.

\begin{tabular}{lcccccc}
\hline Sources & & SS & df & MS & F & p \\
\hline \multirow{4}{*}{ Months } & Chitin & 0.34 & 5 & 0.07 & 3.24 & 0.054 \\
& POC & 1,280 & 5 & 0.26 & 8.89 & 0.002 \\
\multirow{4}{*}{ Fractions } & DW & 20.89 & 5 & 4.18 & 5.13 & 0.014 \\
& Chitin & 0.18 & 2 & 0.09 & 4.24 & 0.046 \\
& POC & 0.22 & 2 & 0.11 & 3.92 & 0.055 \\
Error & DW & 22.74 & 2 & 11.40 & 14.00 & 0.001 \\
& Chitin & 0.21 & 10 & 0.02 & & \\
\multirow{5}{*}{ Total } & POC & 0.29 & 10 & 0.03 & & \\
& DW & 8.14 & 10 & 0.81 & & \\
& Chitin & 3.81 & 18 & & & \\
\hline
\end{tabular}

POC: Particulate organic carbon; DW: Dry weight; * SS: Sum Square; df: Degree of freedom; MS: Mean Square; $p<0.05$ : Significant difference; $p<0.01$ : High significant difference.

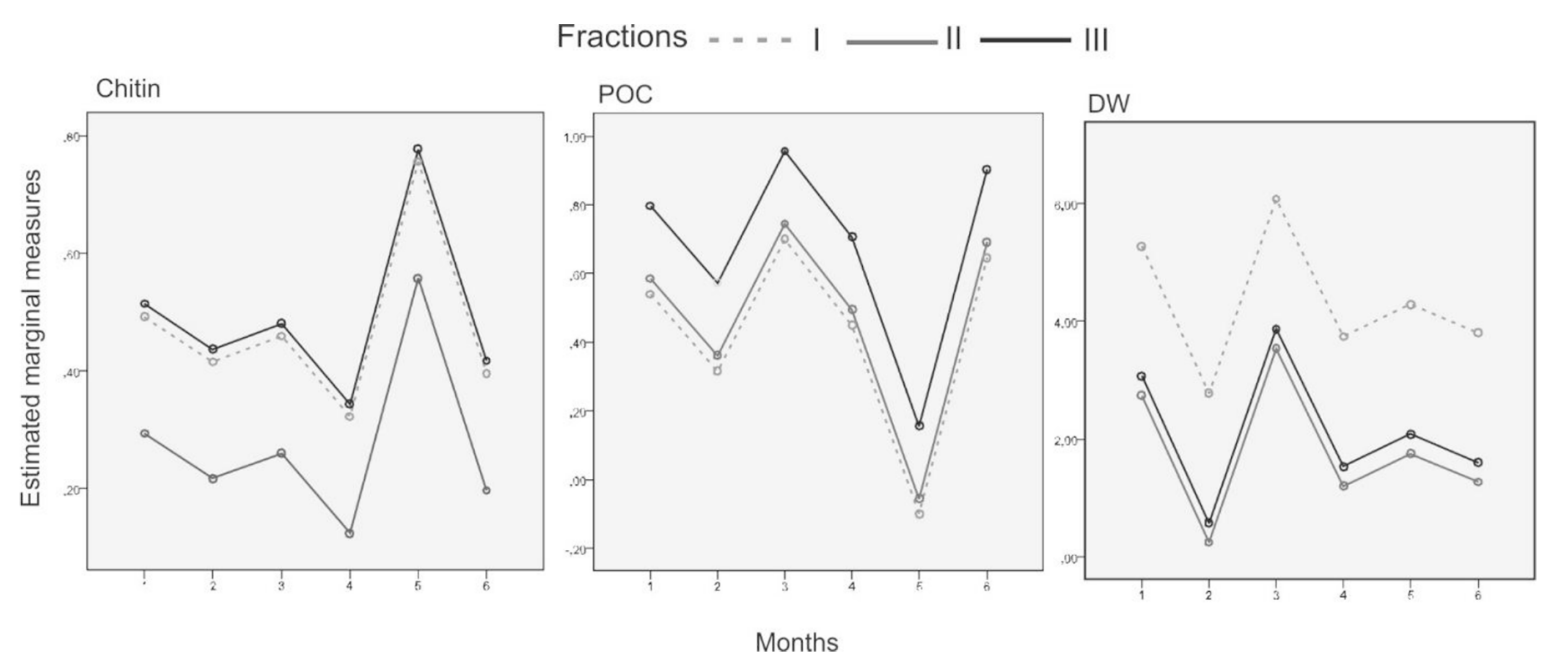

Figure 5. Estimated marginal measures of Chitin, POC and DW showing the differences between fractions and months (Two-way ANOVA

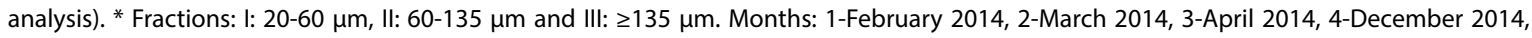
5-January 2015, and 6-February 2015.

and in the POC between January 2015, in which POC was not detected, and the remaining months (Tukey's test, $p \leq 0.05)$.

The PERMANOVA analysis found differences between fractions ( $F: 6.44, p \leq 0.01$ ), being the 60-135 $\mu \mathrm{m}$ size fraction in which the lowest values of the chitin concentration, POC and DW were observed (Table 2, Figure 6). Differences between months were also detected (F: 6.44, $p \leq 0.01$ ).

\section{DISCUSSION}

Our experiment showed that Acartia tonsa with their continuous supply of chitin could be considered a great contributor of this polymer in the different size fractions, which formed part of the organic matter aggregates in this estuarine system. The chitin concentration and its contribution to POC and DW registered in this study reflected that the 20-60 and $\geq 13 \mu \mathrm{m}$ size fractions were the major contribution 
Table 2. The results of PERMANOVA test.

\begin{tabular}{lccccc}
\hline Source & df & SS & MS & Pseudo-F & $\boldsymbol{p}$ \\
\hline Months & 5 & 3225.8 & 645.16 & 6.15 & 0.001 \\
Fractions & 2 & 1350.6 & 675.29 & 6.44 & 0.002 \\
Residual & 10 & 1048.4 & 104.84 & & \\
Total & 17 & 5624.8 & & & \\
\hline
\end{tabular}

* df: Degree of freedom; SS: Sum Square; MS: Mean Square; $p<0.01$ : high significant difference.

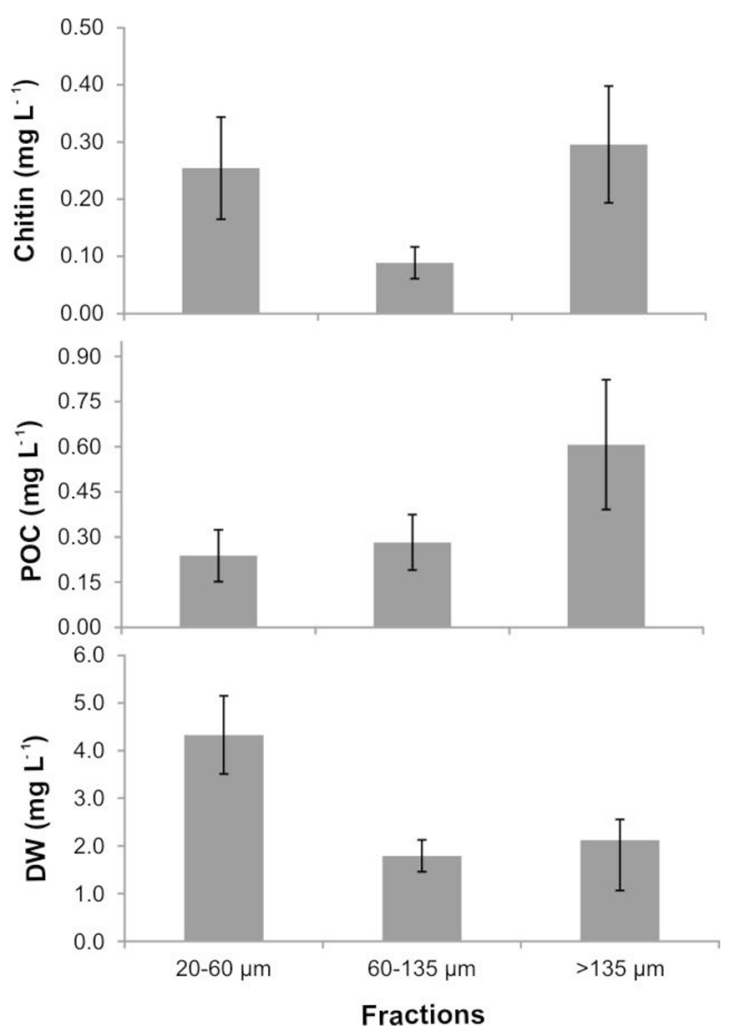

Figure 6. Mean chitin concentration, $\mathrm{POC}, \mathrm{DW}\left(\mathrm{mg} \mathrm{L}^{-1}\right)$ in the seston size fractions, showing the combinations of these variables in each size fraction.

by $A$. tonsa to the chitin pool. These results were in agreement with several studies, which suggested that copepods were an important source of chitin in marine systems (Souza et al., 2011, and references therein), and with those conducted in the seston from in the BBE (Biancalana et al., 2017; 2019).

The highest concentration of chitin in the 20$60 \mu \mathrm{m}$ fraction was presumably due to the high amount of fecal pellets produced by Acatia tonsa together with agglutinated debris and natural food (diatoms and tintinnids). Zooplankton fecal pellets of zooplankton, particularly copepods, contain substantial amounts of chitin, and they are an important source of this biopolymer in marine systems (Turner, 2002; Turner and Ferrante, 1979). Fecal pellets are encased in thin pellicles (peritrophic membranes) formed of chitin and produced in the midgut region of many zooplankters (Foster, 1953). The proportion of chitin in $P O C$ in this size fraction was high during the experimental period compared with the other size fraction. Numerous studies have shown that the contribution of copepod fecal pellets to the total material flux is highly variable, ranging from $<1 \%$ to $99 \%$ (Bathmann et al., 1987; Turner, 2002). Our results suggested us that the great amount of fecal pellets could be one of the sources of chitin in this size fraction, contributing to the POC and DW in this size fraction in the BBE.

Diatoms and tintinnids, which were part of this specie omnivore diet (Diodato and Hoffmeyer, 2008), have been found as a content of zooplankton fecal pellets, being contributors of chitin and part of the fecal pellets flux (Gooday, 1990; Smucker, 1991; Turner, 2002). In addition, diatoms are responsible for the secretion of large amounts of extracellular polymeric substances (EPS) in the microphytobenthos of the BBE (Pan et al., 2013). Extracellular polymer substances from diatoms, bacteria and other microorganisms are the main binding agents of sediment, and also of fecal pellets (Wotton, 2011). Considering the latter, we could assume that in this fraction, the organic aggregate in which fecal pellets and debris are agglutinated is formed by the exudation of EPS by diatoms and bacteria (see Figure $5 \mathrm{~A}$ ), the kind of aggregate in which also fungi structures were distinguished has been observed in seston samples from the BBE (Biancalana et al., 2017b). In this context, and taking into account that in this study the chitin concentration differs between fractions, and chitin contribution to POC, and especially to DW in the 20-60 $\mu \mathrm{m}$ size fraction was important (see Figures 5 and 6), we infer that the agglutinated debris, copepod pellets and natural food (diatoms 
and tintinnids) combined might considerably contribute to the chitin pool in this fraction.

The lowest values of the chitin concentration, POC and DW were observed in the 60-135 $\mu \mathrm{m}$ size fraction (see Figures 5 and 6). In the 60-135 $\mu \mathrm{m}$ size fraction, UE and $\mathrm{HE}$ and nauplii were the materials that Acartia tonsa provided for the chitin pool. Within crustacean, the chitin layer in eggs was observed in several genera of copepods and cladocera (Kaya et al., 2013). Acartia tonsa had different types of eggs, including resting benthic eggs, whose banks were in the inner zone of the BBE (Berasategui et al., 2016; Diodato et al., 2006). This source of chitin together with debris remains of carcasses and natural food (diatoms and tintinnids) were the component of the organic aggregate in this size fraction (see Figure 4B).

The chitin concentration in the $\geq 135 \mu \mathrm{m}$ size fraction, which included living adults, carcasses and exuviae of Acartia tonsa, was higher compared with other fractions, and contributed to POC more than the $20-60 \mu \mathrm{m}$ size fraction in this study. Zooplankton is an important source of this biopolymer, with an estimated mean annual zooplankton chitin biomass of $26.3 \mathrm{mg} \mathrm{m}^{-3}$ (Jeuniaux and Voss-Foucart, 1991). The zooplankton chitin supply from the BBE was mainly presented in the form of degraded particles contributing to a micro-detritus pool in the seston size fraction $\leq 20 \mu \mathrm{m}$. (Biancalana et al., 2017a; 2019). It is known that the carcasses and exuviae of zooplankton represent a concentrated reservoir of chitin for the water column bacteria and fungi (Tang et al., 2010). These organisms are capable of colonizing and degrading chitin rapidly, and have been already observed in the $\leq 20 \mu \mathrm{m}$ size fractions (Biancalana et al., 2017b). The time of colonization and degradation processes on the zooplankton carcasses depended on the carcass type and environmental conditions (Tang et al., 2010, and references therein). In addition, in situ studies of chitin degradation (practical grade chitin from crustacean shells) with the mesh bag technique showed that about $90 \%$ of the original substance was lost after 3 months of exposure in seawater at temperatures between 10 and $18^{\circ} \mathrm{C}$ (Kirchner, 1995).
In our experiment, the chitin samples were obtained after of 72-hour incubations. Thus, we infer that the decomposition of chitin might be in early stages, and consequently the chitin concentration in the $\geq 135 \mu \mathrm{m}$ size fraction exceeded the amount of chitin in the other size fraction during the experiment, showing the importance of carcasses and exuviae in this fraction as a source of chitin.

\section{CONCLUSIONS}

Our results emphasize the potential of Acartia tonsa as a source of chitin in the constitution of organic aggregates in the BBE during warm seasons (Figure 7). The largest part of chitin was found in the $\geq 135 \mu \mathrm{m}$ size fractions, highlighting the importance of this fraction constituted by carcasses and exuviae as a supply of chitin in aquatic systems. Also the great amount of chitin in the $20-60 \mu \mathrm{m}$ size fraction, corroborating that micro-detritus constituted by carcass remains, exuviae and fecal pellets from $A$. tonsa, nano-phytoplankton, and other cells (fungi and bacteria), play an important role contributing to the chitin pool in the BBE during warm season. In addition, $\mathrm{POC}$ and DW presented the highest concentrations in these fractions, stressing their importance for the understanding of the chitin dynamics and their link to the food web in this estuary.

This approach need to be further elaborated and tested considering more variables such as differences between live and dead organisms, egg types, and fungi and bacteria communities, as well as other copepod sources of chitin in the BBE. The inclusion of chitin as a component of organic aggregates and its function in food web models and concepts is urgently needed for a more comprehensive understanding of the ecosystem and biogeochemical cycles in the BBE as well as in other marine and limnetic systems, from selected local systems to global scale ones.

\section{ACKNOWLEDGEMENTS}

This work was supported by the Agencia Nacional de Promoción Científica y Tecnológica (PICT 2796 2013-2015). We would also like to thank Lic. Martín Amodeo for his valuable contribution and suggestions in the statistical analysis. 


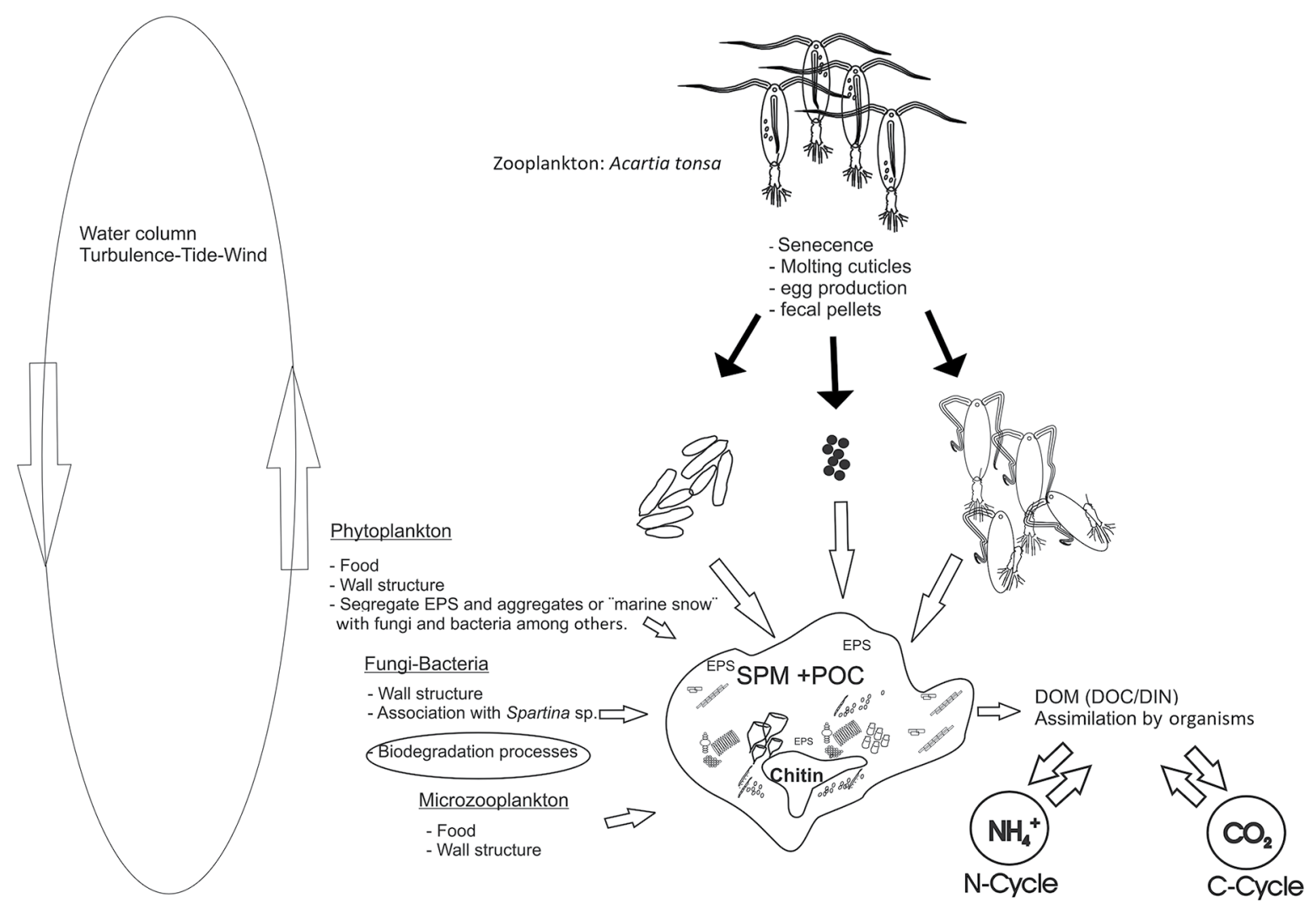

Figure 7. Diagram showing the chitin contribution of Acartia tonsa and its possible function in biogeochemical cycles in the BBE.

\section{AUTHOR CONTRIBUTIONS}

F. B.: Writing - original draft; Writing - review \& editing; Software; A.A.B.: Supervision; Writing - review \& editing.

\section{REFERENCES}

ALLDREDGE, A. L. \& GOTSCHALK, C. C. 1990. The relative contribution of marine snow of different origins to biological processes in coastal waters. Continental Shelf Research, 10(1), 41-58.

BATHMANN, U. V., NOJI, T. T., VOSS, M. \& PEINERT, R. 1987. Copepod fecal pellets: abundance, sedimentation and content at a permanent station in the Norwegian Sea in May/June 1986*. Marine Ecology Progress Series, 38, 45-51.

BEIER, S. \& BERTILSSON, S. 2013. Bacterial chitin degradationmechanisms and ecophysiological strategies. Frontiers in Microbiology, 4(149), 1-12.

BERASATEGUI, A. A., FERNANDEZ-SEVERINI, M. D., MENENDEZ, M. C., BIANCALANA, F., DUTTO, M. S., GUINDER, V., LOPEZABBATE, M. C., CHAZARRETA, J. \& HOFFMEYER, M. S. 2016. Reproductive trade-off of the copepod Acartia tonsa in a hypersaline estuary of the Southwestern Atlantic. Temporal variations in the morphology of eggs. Marine Biology Research, 12(8), 817-829.
BERASATEGUI, A. A., LÓPEZ ABBATE, M. C., D'AGOSTINO, V. PRESTA, M. L., UIBRIG, R., GARCIA, T. M., NAHUELHUAL, E., CHAZARRETA, C. J., DUTTO, M. S., GARCIA, M., CAPITANIO, F. \& HOFFMEYER, M. S. 2018. Mesozooplankton structure and seasonal dynamics in three coastal systems in Argentina: Bahía Blanca Estuary, Pirámide Bay and Ushuaia Bay. In: HOFFMEYER, M. S., SABATINI, M. E., BRANDINI, F. P., CALLIARI, D. L. \& SANTINELLI, N. H. (eds.). Plankton Ecology of Atlantic South America. Switzerland: Springer.

BERGGREEN, U., HANSEN, B. \& KIORBOE, T. 1988. Food size spectra, ingestion and growth of the copepod Acartia tonsa during development: implications for determination of copepod production. Marine Biology, 99(3), 341-352.

BIANCALANA, F., KOPPRIO, G., DUTTO, M. S., BERASATEGUI, A. A., FRINCKE, A., GARZÓN-CARDONA, J. E., PETERKE, D. \& LARA, R. J. 2017a. Chitin determination on marine seston in a shallow temperate estuary (Argentina). Brazilian Journal of Oceanography, 65(2), 146-154.

BIANCALANA, F., KOPPRIO, G. A., LARA, R. J. \& ALONSO, C. 2017b. A protocol for a simultaneous identification of chitin-containing particles and their associated bacteria. Systematic and Applied Microbiology, 40(5), 314-320.

BIANCALANA, F., FERNÁNDEZ-SEVERINI, M. D., VILLAGRAN, D. M., BERASATEGUI, A. A., TARTARA, M. N., SPETTER, C. V., GUINDER, V., MARCOVECCHIO, J. E. \& LARA, R. 2019. Assessment of chitin variation in seston of a temperate estuary (Bahía Blanca, Argentina). Environmental Earth Sciences, 78, 1-14. 
BROGLIO, E., JÓNASDÓTTIR, S. H., CALBET, A., JAKOBSEN, H. H. \& SAIZ, E. 2003. Effect of heterotrophic versus autotrophic food on feeding and reproduction of the calanoid copepod Acartia tonsa: relationship with prey fatty acid composition. Aquatic Microbial Ecology, 31(3), 267-278.

CALLIARI, D., ANDERSEN BORG, M. C., THOR, P., GOROKHOVA, E. \& TISELIUS, P. 2008. Instantaneous salinity reductions affect the survival and feeding rates of the co-occurring copepods Acartia tonsa Dana and A. clausi Giesbrecht differently. Journal of Experimental Marine Biology and Ecology, 362, 18-25.

CALLIARI, D., MARC-ANDERSEN, C., THOR, P., GOROKHOVA, E. \& TISELIUS, P. 2006. Salinity modulates the energy balance and the productive success of co-occurring copepods Acartia tonsa and A. clausi in different ways. Marine Ecology Progress Series, 312, 177-188.

DIODATO, S. L., BERASATEGUI, A. A. \& HOFFMEYER, M. S. 2006. Morphological types and seasonal variation in eggs of zooplankton species from bottom sediments in Bahía Blanca Estuary, Argentina*. Brazilian Journal of Oceanography, 54(2-3), 161-167.

DIODATO, S. L. \& HOFFMEYER, M. S. 2008. Contribution of planktonic and detritic fractions to the natural diet of mesozoplankton in Bahía Blanca Estuary. Hydrobiologia, 614, 83-90.

DURBIN, A. G. \& DURBIN, E. G. 1981. Standing stock and estimated production rates of phytoplankton and zooplankton in Narragansett Bay, Rhode Island. Estuaries, $4(1), 24-41$.

DUTTO, M. S., GENZANO, G. N., SCHIARITI, A., LECANDA, J., HOFFMEYER, M. S. \& PRATOLONGO, P. D., 2017. Medusae and ctenophores from the Bahía Blanca Estuary and neighboring inner shelf (Southwest Atlantic Ocean, Argentina). Marine Biodiversity Records, 10, 1-14.

DUTTO, M. S., LÓPEZ ABBATE, M. C., BIANCALANA, F., BERASATEGUI, A. A. \& HOFFMEYER, M. S. 2012. The impact of sewage on environmental quality and the mesozooplankton community in a highly eutrophic estuary in Argentina. ICES Journal of Marine Science, 69(3), 399-409.

DURKIN, C. A., MOCK, T. \& ARMBRUST, E. V. 2009. Chitin in diatoms and its association with the cell wall. Eukaryotic Cell, 8(7), 1038-1050.

ESCARAVAGE, V. \& SOETAERT, K. 1995. Secondary production of the brackish copepod communities and their contribution to the carbon fluxes in the Westerschelde estuary (The Netherlands). Hydrobiologia, 311, 103-114

FOSTER, G. R. 1953. Peritrophic membranes in the Caridea (Crustacea Decapoda). Journal of the Marine Biological Association of the United Kingdom, 32(2), 315-318.

FREIJE, R. H., SPETTER, C. V., MARCOVECCHIO, J. E., POPOVICH, C. A., BOTTÉ, S. E. \& NEGRIN, V. L. 2008. Water chemistry and nutrients of the Bahía Blanca estuary. In: NEVES, R., BARETTA, J. \& MATEUS, M. (eds.). Perspectives on Integrated Coastal Zone Management in South America. Lisbon, Portugal: ISTPress.

GOODAY, G. W. 1990. Physiology of microbial degradation of chitin and chitosan. Biodegradation, 1(2-3), 177-190.

GUINDER, V. A., MOLINERO, J. C., POPOVICH, C. A., MARCOVECCHIO, J. E. \& SOMMER, U. 2012. Dominance of the planktonic diatom Thalassiosira minima in recent summers in the Bahia Blanca Estuary, Argentina. Journal of Plankton Research, 34(11), 995-1000.
GUINDER, V. A., POPOVICH, C. A., MOLINERO, J. C. \& PERILLO, G. M. E. 2010. Long-term changes in phytoplankton phenology and community structure in the Bahía Blanca Estuary, Argentina. Marine Biology, 157, 2703-2716.

HANSEN, B., FOTEL, F. L., JENSEN, N. J. \& MADSEN, S. D. 1996. Bacteria associated with a marine planktonic copepod in culture. II. Degradation of fecal pellets produced on a diatom, a nanoflagellate or a dinoflagellate diet. Journal of Plankton Research, 18(2), 275-288.

HEINLE, D. R. 1966. Production of a calanoid copepod, Acartia Tonsa, in the Patuxent River Estuary. Chesapeake Science, 7(2), 59-74.

HOFFMEYER, M. S. 2004. Decadal change in zooplankton seasonal succession in the Bahía Blanca Estuary, Argentina, following introduction of two zooplankton species. Journal of Plankton Research, 26(2), 181-89.

HOFFMEYER, M. S. 2007. Mesozooplancton. In: PICCOLO, M. C. \& HOFFMEYER, M. S. (eds.). El Ecosistema del Estuario de Bahía Blanca. Bahía Blanca, Argentina: Editorial de la Universidad Nacional del Sur (EdiUNS).

JEUNIAUX, C. H. \& VOSS-FOUCART, M. F. 1991. Chitin biomass and production in the marine environment. Biochemical Systematic and Ecology, 19(5), 347-356.

JOHNSTONE, J. 1908. Conditions of life in the sea. In: SHIPLEY, A. E. (ed.). Cambridge Biological Series. Cambridge: University Press.

KAYA, M., SARGIN, I., TOZAK, K. Ö., BARAN, T., ERDOGAN, S. \& SEZEN, G. 2013. Chitin extraction and characterization from Daphnia magna resting eggs. International Journal of Biological Macromolecules, 61, 459-464.

KIRCHNER, M. 1995. Microbial colonization of copepod body surfaces and chitin degradation in the sea. Helgolander Meeresunters, 49, 201-212.

KIORBOE, T., MOHLENBERG, F. \& HAMBURGER, K. 1985. Bioenergetics of the planktonic copepod Acartia tonsa: relation between feeding, egg production and respiration, and composition of specific dynamic action. Marine Ecology Progress Series, 26, 85-97.

LARA, R. J., NEOGI, S. B., ISLAM, S., MAHMUD, Z. H., ISLAM, S., DEBASISH, P., DEMOZ, B. B., YAMASAKI, S., NAIR, G. B. \& KATTNER, G. 2011. Vibrio cholerae in waters of the Sundarban mangroves: relationship with biogeochemical parameters and chitin content in seston size fractions. Wetlands Ecology and Management, 19(1), 109-119.

LEANDRO, S. M., TISELIUS, P. \& QUEIROGA, H. 2006. Growth and development of nauplii and copepodites of the estuarine copepod Acartia tonsa from southern Europe (Ria de Aveiro, Portugal) under saturating food conditions. Marine Biology, 150(1), 121-129.

LEANDRO, S. M., TISELIUS, P., MARQUÉS, S. C., AVELELAS, F., CORREIA, C. R., SÁ, P. \& QUEIROGA, H. 2014. Copepod production estimated by combining in situ data and specific temperature-dependent somatic growth models. Hydrobiologia, 741(1), 139-15.

MAUCHLINE, J. 1998. The Biology of Calanoid Copepods. Oxford: Elsevier Academic Press.

MONTGOMERY, M. T., WELSCHMEYER, N. A. \& KIRCHMAN, D. L. 1990. A simple assay for chitin: application to sediment trap samples from the subarctic Pacific. Marine Ecology Progress Series, 64, 301-308. 
MUXAGATA, E., AMARAL, W. J. A. \& BARBOSA, C. N. 2012. Acartia tonsa production in the Patos Lagoon estuary, Brazil. ICES Journal of Marine Science, 69(3), 475-482.

NICOL, S. \& HOSIE, G. W. 1993. Chitin production by krill. Biochemical Systematics and Ecology, 21(2), 181-184.

PAN, J., BOURNOD, C. N., PIZANI, N. V., CUADRADO, D. G. \& CARMONA, N. B. 2013. Characterization of microbial mats from a siliciclastic tidal flat (Bahía Blanca estuary, Argentina). Geomicrobiology Journal, 30(8), 665-674.

PECK, M. A. \& HOLSTE, L. 2006. Effects of salinity, photoperiod and adult stocking density on egg production and egg hatching success in Acartia tonsa (Calanoida: Copepoda): optimizing intensive cultures. Aquaculture, 255(1-4), 341350.

PERILLO, G. M. E., PICCOLO, M. C., PARODI, E. \& FREIJE, R. H. 2001. The Bahía Blanca estuary, Argentina. In: SEELIGER, U. \& KJERFVE, B. (eds.). Coastal Marine Ecosystems of Latin America, Ecological Studies. New York: Springer.

PETTIGROSSO, R. E. \& BARRÍA DE CAO, M. S. 2007. Ciliados planctónicos. In: PICCOLO, M. C. \& HOFFMEYER, M. (eds.). El ecosistema del estuario de Bahía Blanca. Bahía Blanca, Argentina: Editorial de la Universidad Nacional del Sur (EdiUNS).

POPOVICH, C. A. \& MARCOVECCHIO, J. E. 2008. Spatial and temporal variability of phytoplankton and environmental factors in a temperate estuary of South America Atlantic coast, Argentina). Continental Shelf Research, 28, 236-244.
SABATINI, M. E. 1989. Ciclo anual del copépodo Acartia tonsa Dana 1849 en la zona interna de Bahía Blanca (Provincia de Buenos Aires, Argentina). Scientia Marina, 53, 847-56.

SIMON, M., GROSSART, H. P., SCHWEITZER, B. \& PLOUG, H. 2002. Microbial ecology of organic aggregates in aquatic ecosystems. Aquatic Microbial Ecology, 28, 175-211.

SMUCKER, R. A. 1991. Chitin primary production. Biochemical Systematics and Ecology, 19(5), 357-369.

SOUZA, C. P., ALMEIDA, B. C., COLWELL, R. R. \& RIVERA, I. N. G. 2011. The importance of chitin in the marine environment. Marine Biotechnology, 13, 823-830.

STRICKLAND, J. H. D. \& PARSONS, T. R. 1968. A practical handbook of seawater analysis. Ottawa: Fisheries Research Board of Canada.

STOTTRUP, J. G. 2000. The elusive copepods: their production and suitability in marine aquaculture. Aquaculture Research, 31, 703-711.

TANG, K. W., TURK, V. \& GROSSART, H. P. 2010. Linkage between crustacean zooplankton and aquatic bacteria. Aquatic Microbial Ecology, 61, 261-277.

TURNER, J.T. 2002.Zooplankton fecal pellets, marine snow and sinking phytoplankton blooms. Aquatic Microbial Ecology, 27, 57-102.

TURNER, J. T. \& FERRANTE, J. G. 1979. Zooplankton fecal pellets in aquatic ecosystems. BioScience, 29(11), 670-677.

WOTTON, R. S. 2011. EPS (Extracellular Polymeric Substances), silk, and chitin: vitally important exudates in aquatic ecosystems. Journal of the North American Benthological Society, 30(3), 762-769. 